


\title{
The role of the factors determining national character in building civil society
}

\author{
DOI: https://doi.org/10.46398/cuestpol.3969.48
}

\author{
Serhii O. Komnatnyi * \\ Oleg S. Sheremet ** \\ Viacheslav E. Suslykov *** \\ Kateryna S. Lisova \\ Stepan D. Svorak *****
}

\begin{abstract}
The article deals with the mechanism of impact of sociopsychological phenomena such as the national character and the political mentality in the construction and functioning of civil society. It aims to show the impact of climate, religion, and the perception of happiness on the state of civil society through details of a national nature. The main research method is to compare data from global research on the state of civil society with data from climatic conditions, dominant religions, and happiness indices. The article proves coincidently that these factors are reflected in such essential characteristics of civil society as «openness» and «closedmindedness». The interaction between the national character and the construction of civil society has two stages. It is concluded that the results obtained are important to evaluate the prospects for the construction and development of civil society in different countries and regions of the world. Further research in this direction involves the study of other aspects of the impact of national character and political mindset on the functioning of
\end{abstract} civil society.

Keywords: civil society; national character; political mentality; climatic factor; religious factor.

* PhD in Pedagogy, Senior Lecturer, Department of Civil Law Disciplines, National Academy of Internal Affairs. ORCID ID: https://orcid.org/oooo-0002-2124-2047. Email: serhkomnatniy@ukr.net

** Doctor of Law, Associate Professor, Professor, Taras Shevchenko National University "Chernihiv Collegium". ORCID ID: https://orcid.org/oooo-0002-9512-991X. Email: sheremet.ol.cn@yahoo.com

*** PhD in History, Associate Professor, Department of Social Sciences and Humanities, Donetsk Law Institute of MIA of Ukraine. ORCID ID: https://orcid.org/oooo-00o3-3803-6191. Email: suslykovviach@ukr.net

**** PhD in History, Head of Department, General Theoretical Legal and Socio-Humanitarian Disciplines, Kyiv University of Law the National Academy of Sciences of Ukraine. ORCID ID: https://orcid. org/oooo-0oo2-2664-7721. Email: katerynal73196@gmail.com

***** Doctor of Law, Professor, Department of Theory and History of State and Law, Vasyl Stefanyk Precarpathian National University. ORCID ID: https://orcid.org/oooo-0003-3116-1221. Email: 45professor_svsd_@ukr.net 


\section{El papel de los factores que determinan el carácter nacional en la construcción de la sociedad civil}

\section{Resumen}

El artículo trata sobre el mecanismo de impacto de fenómenos sociopsicológicos como el carácter nacional y la mentalidad política en la construcción y funcionamiento de la sociedad civil. Su objetivo es mostrar el impacto del clima, la religión y la percepción de la felicidad en el estado de la sociedad civil a través de detalles de carácter nacional. El principal método de investigación es la comparación de los datos de la investigación global sobre el estado de la sociedad civil con los datos de las condiciones climáticas, las religiones dominantes y los índices de felicidad. El artículo prueba fehacientemente que estos factores se reflejan en características tan esenciales de la sociedad civil como la "apertura" y la "cerrazón". La interacción entre el carácter nacional y la construcción de la sociedad civil tiene dos etapas. Se concluye que los resultados obtenidos son importantes para evaluar las perspectivas de construcción y desarrollo de la sociedad civil en diferentes países y regiones del mundo. La investigación adicional en esta dirección implica el estudio de otros aspectos del impacto del carácter nacional y la mentalidad política en el funcionamiento de la sociedad civil.

Palabras clave: sociedad civil; carácter nacional; mentalidad política; factor climático; factor religioso.

\section{Introduction}

The problem of civil society is one of the most acute in modern sociopolitical discourse. In the euphoria of the 1990's, civil society was seen as a universal means of establishing a global liberal-democratic order that would finally ensure peace and happiness throughout the world. But this ideal began to fail after the crisis of 2008. In the middle of the first decade of the 21st century, it became clear that this recipe is not a kind of panacea to finding solutions to different kinds of problems faced by not only developing countries, but also the democratic world as a whole. Biden (2020) states that democracies - paralyzed by hyper partisanship, hobbled by corruption, weighed down by extreme inequality -are having a harder time delivering for their people.

It should be emphasized that disappointment with civil society projects is due to a superficial understanding of its essence, incorrect assessment of the driving forces of its development, and attempts to build it according to a single unified pattern around the world. The creation of a new alliance of democratic forces announced by the new US President 
requires a revision of these views. Therefore, the identification of factors that influence the process of building civil society in different socio-political conditions has appeared on the agenda of political sciences. The study of socio-psychological aspects that underlie the genesis and functioning of civil society as an anthropocentric system helps to establish an objective scientific position on its prospects in different countries and prevent errors in socio-political forecasting.

Civil society issues are the subject of many social and political studies. The most famous studies were included in The Oxford Handbook of Civil Society edited by Edwards (2013). Kenny (2020) presents an extended analysis of current political discourse about civil society. But no studies cover anthropological, in particular, socio-psychological aspects of civil society.

Some researchers explore how such a socio-psychological phenomenon as national character manifests itself in modern political systems (Inkeles, 2017). But these scholars do not focus on national character and mentality in the context of building and functioning of civil society, and do not use the data on underlying factors.

- The aim of the article is to identify the role of external factors and internal determinants of national character and political mentality in building and functioning of civil society.

- This aim involves the fulfilment of the following research objectives:

- compare the state of civil society in different countries with the climatic conditions of their location.

- correlate such characteristics of civil society as 'openness' and 'closedness' with the dominant religion.

- $\quad$ analyze the dependence of the state of civil society on the factors that determine the feeling of happiness inherent in a certain type of national character.

\section{Literature Review}

For contemporary scholars, social activists and development professionals, civil society is a collection of diverse interest groups and social organizations. Most cited dictionaries propose to interpret civil society as the 'third sector' of society, "the set of intermediate associations which are neither the state nor the (extended) family; civil society, therefore, includes voluntary associations and firms, as well as other corporate bodies" (McLean and McMillan, 2009), or more teleologically as "the organizations within a society that works to promote the common good, usually taken to include 
state-run institutions, families, charities, and community groups" (Collins Online English Dictionary, 2021).

Those interpretations of this term are based on the positions of institutionalism. They are linked to the rationalism of the Renaissance and the Enlightenment and are rooted in the works of Machiavelli, Moore, Hobbes, Locke, de Saint-Simon. But these main current usages are derived from Hegel's liberal theory adapted by de Tocqueville, Marx, and Tönnies. Edwards (2013) points out to the shortcomings of this interpretation, which caused a mimicry of the essence of civil society concept:

\footnotetext{
"First, a conversation about democracy and self-expression has become increasingly technocratic, dominated by elites who seek to shape civil society for their ends and increasingly mimicking the language and practices of businesses and market-based investment. Second, much current civil society research, funding, and policymaking are highly ethnocentric, informed by a partial reading of work dating back to the writings of Alexis de Tocqueville in mid-nineteenthcentury America which placed voluntary associations of various kinds at the centre of thinking and action of civil society, but later translated to settings with completely different cultures of collective action, histories, and contemporary conditions. It is this sense of mimicry that has stimulated the export of models developed in North America and Western Europe to other parts of the world with unsurprisingly disappointing results" (Edwards, 2013: 7).
}

The analysis of these failures leads to the assumption that "perhaps there is something written into the genetic code of human beings that resists attempts to bureaucratize the self-organizing principles of civil society or reduce citizen action to a subset of the market" (ibid). This assumption is not further developed by Edwards (2013) or other authors, but it is the first element in the structure of our hypothesis because the common genetic code is the factor that forms the basis of the ethnos.

We make an ascent from ethnos as a genetic community to ethos as a moral community for further theoretical substantiation of the hypothesis about predetermined establishment of civil society. It should be noted that the term "civil society" goes back to Aristotle's phrase koinōnía politik $\square$

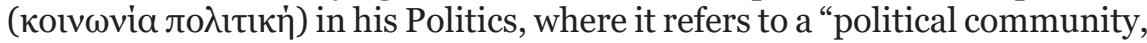
commensurate with the Greek city-state (polis) characterized by a shared ethos (Lord, 2013). Ethos is a Greek word meaning "character" that is used to describe the guiding beliefs or ideals that characterize a community, nation, or ideology. In modern usage, ethos denotes the disposition, character, or fundamental values peculiar to a specific person or group (national ethos) (Cambridge Dictionary, 2021). So, the ethos is a moral core of a national character and political mentality, it is the so-called "spirit of people". According to Aristotle, it defines the forms of civil society.

It is necessary to consider the factors that determine the specifics of the ethos of different peoples to show how the national character influences 
the building of civil society. Thus, the logic of the development of the theoretical substantiation of our hypothesis leads the focus of the study to Montesquieu's meteorological climate theory, outlined in The Spirit of Law (1748). This concept holds that climate may substantially influence the nature of man and his society. Initially, Montesquieu showed how climate affects the peculiarities of individual character and national ethos. He argued that the feebleness of peoples of warm climates almost always made slaves of them, and the courage of peoples of cold climates kept them free. That is an effect that derives from its natural cause (Stewart, 2018). Then he proved the dependence of social order and social norms on these determinants:

If it is true that the character of the mind and the passions of the heart are extremely different in the various climates, laws must be relative both to the difference of those passions and the difference of those characters... Laws have a very great relationship to how various peoples procure their subsistence (Stewart, 2018: 32).

Modern researchers confirmed those findings. McCrae et al., (2007), that warmth and wealth are common determinants of national stereotypes, but that there are also idiosyncratic influences on the perceptions of individual nations.

Religion is the next key factor determining the formation of ethos, and hence - civil society. Thinkers have pointed to this factor since ancient times. Stewart (2018) argued the same as well. The Christian religion commands men to love each other, so there is no doubt that every people should have the best political laws and the best civil laws, because they are, next to themselves, the greatest good that men can give and receive. That moderate government is more compatible with the Christian religion, and despotic government - with the Mohammedan religion.

The "spirit of the nations" from Weber (2002) The Protestant Ethic and the Spirit of Capitalism cannot be ignored in this context. After defining the "spirit of capitalism" in Germany, Weber argued that there are many reasons to find its origins in the religious ideas of the Reformation. Then he attributed this relationship between capitalism and Protestantism to certain accidental psychological consequences of the notions of predestination and calling in Puritan theology. It is important how Weber revealed its role in building certain forms of civil society:

So that a manner of a life well adapted to the peculiarities of the capitalism... could come to dominate others, it had to originate somewhere, and not in isolated individuals alone, but as a way of life common to the whole groups of man (Weber, 2002: 78).

Current researchers confirm the influence of religious ethical norms enshrined in the mentality on the formation of such components of civil 
society as truth and social distance. In particular, Dingley (2009) argues that national identity is closely linked to the religion, which in turn is closely linked to the ideas of truth. Different religions will form and transmit different ideas of truth, both moral and cognitive, and transmit them and socialize their members into holding them. The findings of Bilali et al., (2018) the importance of considering religious identity and meaning attached to social categories in making predictions about the influence of identification with different social categories on social distance.

It should be noted that, thinkers considered civility as an orientation toward the common good and happiness from the time of classical Greece. Edwards (2013) emphasizes: "How do the structures of associational life and the dynamics of the public sphere help or hinder the achievement of "good society" goals? This is the most important question in the civil society debate". This question comes from the lifelong problem of the existence of a free individual in a society. Although each person has a sense of happiness, individuals must reach a public agreement on interaction to achieve "the greatest happiness for the greatest number of people" in the process of communication. Helliwell et al., (2020) help to formulate the answer.

The primary result from their empirical analysis of the social environment is that several kinds of individual and social trust, as well as social connections have large direct and indirect impacts on life evaluation. The indirect impacts, which are measured by allowing the effects of trust to buffer the estimated well-being effects of bad times, show that both social trust and institutional trust reduce the inequality of well-being by increasing the resilience of individual well-being to various types of adversity, including perceived discrimination, ill-health, unemployment, low income, and fear when walking the streets at night. Average life satisfaction is estimated to be almost one point higher (0.96 points) in a high-trust environment as compared to a low-trust environment. These researches also argue that the social environment is dealt with in detail, they consider happiness in the Nordic countries and find that higher personal and institutional trust are key factors in explaining why life evaluations are so high in those countries. Together the changes in trust and social connections explain 60\% of the happiness gap between the Nordic countries and Europe as a whole (Helliwell et al., 2020).

Social origins theory helps us to discover the meaning of the national "happiness formula" as well. This theory is used to analyse results of the national survey on civic participation in Sweden. The results show that such civic virtue as charitable giving is a component of the Swedish national character, and has a significant impact on civil society functioning. From this point of view, we can agree with Mahajan (2021) interpretation of civil society as a sphere where the collective "we" emerges and acts to affirm the Kantian ideals of human dignity and equal respect. 
Serhii O. Komnatnyi, Oleg S. Sheremet, Viacheslav E. Suslykov, Kateryna S. Lisova y Stepan D. Svorak

780 The role of the factors determining national character in building civil society

\section{Methods}

A critical analysis of modern concepts of civil society and consideration of scientific approaches to understanding deep predetermination of national character and mentality as the driving forces of building civil society is the background for substantiating the research methodology. This methodology is designed to reveal the anthropocentric but not always rationalistic essence of building civil society. Therefore, we take climatic conditions as the first variable in our research. Then, religion acts as the second variable in our research. And we chose the feeling of happiness as the third variable in our research, which comprehensively reflects the influence of national character on building civil society.

The methods are consistent with the aim and objectives of this research and include:

- the comparative analysis of the state of civil society in different countries and their climatic conditions.

- the search for correlation between such characteristics of civil society as "openness" and "closedness" with the dominant religion.

- the analysis of the statistical data of happiness index in different countries and the calculation of its average value in "open society" and "closed society" countries.

- summarizing the data from these analyses and drawing a conclusion about the role of the factors determining national character in building civil society.

The research materials are based on:

- the data from global studies on the state of civil society in different countries, published by international civil society organization CIVICUS (2019): World Alliance for Citizen Participation.

- the data on climatic conditions (Provisional Report on the State of the Global Climate 2020, Climate Zone Shiny Map 2020 and World Climate Maps 2020 demonstrated by World Meteorological Organization (2020a; 2020b; 2021).

- the data about religion in the world (The Global Religious Landscape 2020: A Report on the Size and Distribution of the World's Major Religious Groups presented by CIA World Factbook (2020), and Pew Research Center (2020).

- the data on happiness indexes in different countries (World Happiness Report 2020 prepared by UN Sustainable Development Solutions Network, and Center for Sustainable Development Columbia University (Helliwell et al. 2020)). 
For clarity of research results, the research sample includes countries that belong to the two ultimate categories: "open society" - 19 countries, and "closed society" - 18 countries, by CIVICUS (2019): The State of Civil Society.

\section{Results}

The research results are presented in the tables prepared by the author using the materials mentioned above and subsequent data analysis.

The first block (Tables 1 and 2) shows the dependence of the level of openness of civil society on climatic indicators of temperature and humidity.

Table 1. Climatic factor in "open society" countries

\begin{tabular}{|c|c|c|c|c|c|}
\hline \# & Country & Climate zone & $\begin{array}{l}\text { Winter } \\
\text { t (Co) - } \\
\text { zone }\end{array}$ & $\begin{array}{l}\text { Summer } \\
\text { t (C') - } \\
\text { zone }\end{array}$ & $\begin{array}{l}\text { Wet zone } \\
\text { (mear) } \\
\text { year) }\end{array}$ \\
\hline 1 & $\begin{array}{l}\text { Canada } \\
\text { (main part) }\end{array}$ & Temperate / Subpolar & $-24-8$ & $+8+16$ & 500-1000 \\
\hline 2 & Iceland & Temperate / Subpolar & -8 & +8 & $500-1000$ \\
\hline 3 & Norway & Temperate / Subpolar & o & +12 & $500-1000$ \\
\hline 4 & Sweden & Temperate / Subpolar & $\mathrm{O}$ & +12 & $500-1000$ \\
\hline 5 & Finland & Temperate / Subpolar & $\mathrm{O}$ & +12 & $500-1000$ \\
\hline 6 & Denmark & Temperate & o & +16 & $500-1000$ \\
\hline 7 & Estonia & Temperate & $\mathrm{O}$ & +16 & $500-1000$ \\
\hline 8 & Lithuania & Temperate & $\mathrm{O}$ & +16 & $500-1000$ \\
\hline 9 & Germany & Temperate & $\mathrm{O}$ & +16 & $500-1000$ \\
\hline 10 & Netherland & Temperate & 0 & +16 & $500-1000$ \\
\hline 11 & Belgium & Temperate & $\mathrm{O}$ & +16 & $500-1000$ \\
\hline 12 & Czech Rep. & Temperate & $\mathrm{O}$ & +20 & $500-1000$ \\
\hline 13 & Austria & Temperate & $\mathrm{O}$ & +20 & $500-1000$ \\
\hline 14 & Switzerland & Temperate & $\mathrm{O}$ & +20 & $500-1000$ \\
\hline 15 & Ireland & Temperate & +8 & +16 & 1000-2000 \\
\hline 16 & Portugal & Subtropical & +8 & +22 & $500-1000$ \\
\hline 17 & New Zeeland & Temperate / Subtropical & +8 & +16 & 1000-2000 \\
\hline 18 & Uruguay & Subtropical & +8 & +16 & 500-1000 \\
\hline 19 & Surinam & Tropical & +24 & +24 & 2000-3000 \\
\hline
\end{tabular}

Source: Based on World Meteorological Organization (2020a; 2020b 2021). 
Serhii O. Komnatnyi, Oleg S. Sheremet, Viacheslav E. Suslykov, Kateryna S. Lisova y Stepan D. Svorak

Out of the 19 'open society' countries, 16 countries (84\%) are located in the temperate zone (including 5 that combine the temperate and subpolar zones, and 1 (New Zeeland) with the temperate and subtropical zones). 2 countries are located in subtropics and 1 (Surinam) in tropics. Moreover, all countries are located in more or less humid zones. None of these countries are located in a hot arid climate. Only in Canada, due to its vast territory, there are areas of continental climate, but cold.

Table 2. Climatic factor in 'closed-society' countries

\begin{tabular}{|c|c|c|c|c|c|}
\hline \# & Country & Climate zone & $\begin{array}{l}\text { Winter } \\
\text { t (Co) - } \\
\text { zone }\end{array}$ & $\begin{array}{l}\text { Summer } \\
\text { t (C') - } \\
\text { zone }\end{array}$ & $\begin{array}{l}\text { Wet zone } \\
\text { (mm per } \\
\text { year) }\end{array}$ \\
\hline 1 & $\begin{array}{l}\text { China } \\
\text { (main part) }\end{array}$ & $\begin{array}{l}\text { Temperate / } \\
\text { Subtropical }\end{array}$ & $-24+8$ & $+16+24$ & $250-1000$ \\
\hline 2 & $\begin{array}{l}\text { Lao People } \\
\text { Democratic Rep. }\end{array}$ & Tropical & +24 & +24 & $1000-2000$ \\
\hline 3 & Viet Nam & Tropical & +24 & +24 & 2000-3000 \\
\hline 4 & Uzbekistan & Subtropical & +8 & +24 & $\leq 100$ \\
\hline 5 & Turkmenistan & Subtropical & +8 & +24 & $\leq 100$ \\
\hline 6 & Iran Islamic Rep. & Subtropical & +8 & +24 & $100-250$ \\
\hline 7 & Azerbaijan & Subtropical & +8 & +24 & $100-250$ \\
\hline 8 & Iraq & Subtropical & +12 & +24 & $\leq 100$ \\
\hline 9 & Syrian Arab Rep. & Subtropical & +12 & +24 & $\leq 100$ \\
\hline 10 & Saudi Arabia & $\begin{array}{l}\text { Subtropical / } \\
\text { Tropical }\end{array}$ & +16 & +32 & $\leq 100$ \\
\hline 11 & Yemen & Tropical & +24 & +32 & $\leq 100$ \\
\hline 12 & Eritrea & Tropical & +24 & +32 & 250-500- \\
\hline 13 & Egypt & Subtropical & +16 & +32 & $\leq 100$ \\
\hline 14 & Libya & Subtropical & +16 & +32 & $\leq 100$ \\
\hline 15 & South Sudan & Tropical & +24 & +32 & $1000-2000$ \\
\hline 16 & Central African Rep. & Tropical & +24 & +24 & 1000-2000 \\
\hline 17 & Equatorial Guinea & Tropical & +24 & +24 & 2000-3000 \\
\hline 18 & Cuba & Tropical & +24 & +24 & $1000-2000$ \\
\hline
\end{tabular}

Source: Based on World Meteorological Organization (2020a; 2020b 2021).

Out of the 18 "closed society" countries, 17 countries (94.4\%) are located in hot climates. A significant part of the territory of China is also located 
there. There are 8 countries located in tropical climates, the same number - in subtropical, and Saudi Arabia -in both. There are 11 countries (61\%) located in arid climates, and 6 countries (33\%) - in humid climates. None of these countries are located in the temperate zone. But there are different temperature and humidity conditions in China.

The second block (Tables 3 and 4) demonstrates the correlation between such characteristics of society as "openness" and "closedness" with the dominant religion.

Table 3. Religious factor in "open-society" countries

\begin{tabular}{|c|c|c|}
\hline \# & Country & Religious denominations \\
\hline 1 & Canada & $\begin{array}{l}\text { Christian Roman Catholic } 43 \% \text {, Protestant 23\% (including } \\
\text { United Church 10\%, Anglican 7\%, Baptist 2\%, Lutheran 2\%), } \\
\text { other Christian 4\%, Muslim 2\%, none } 16 \%\end{array}$ \\
\hline 2 & Iceland & $\begin{array}{l}\text { Christian Lutheran Church of Iceland } 85.5 \% \text {, Reykjavik Free } \\
\text { Church 2.1\%, Roman Catholic Church } 2 \% \text {, Hafnarfjorour Free } \\
\text { Church 1.5\%, other Christian 2.7\%, other or unspecified 3.8\%, } \\
\text { unaffiliated } 2.4 \%\end{array}$ \\
\hline 3 & Norway & $\begin{array}{l}\text { Christian Evangelical Lutheran 86\% (state church), } \\
\text { Pentecostal 1\%, Roman Catholic 1\%, other Christian 2\% }\end{array}$ \\
\hline 4 & Sweden & $\begin{array}{l}\text { Christian Lutheran } 87 \% \text {, Roman Catholic, Orthodox, } \\
\text { Baptist, Muslim, Jewish, Buddhist }\end{array}$ \\
\hline 5 & Finland & $\begin{array}{l}\text { Christian Evangelical Lutheran 84\%, Greek Orthodox 1\%, } \\
\text { other Christian 1\%, none 14\% }\end{array}$ \\
\hline 6 & Denmark & $\begin{array}{l}\text { Christian Evangelical Lutheran 95\%, other Protestant and } \\
\text { Roman Catholic 3\%, Muslim 2\% }\end{array}$ \\
\hline 7 & Estonia & $\begin{array}{l}\text { Christian Evangelical Lutheran 14\%, Russian Orthodox } 13 \% \text {, } \\
\text { other Christian (including Methodist, Seventh-Day Adventist, } \\
\text { Roman Catholic, Pentecostal) 1\%, unaffiliated 34\%, none } 6 \%\end{array}$ \\
\hline 8 & Lithuania & $\begin{array}{l}\text { Christian Roman Catholic 79\%, Russian Orthodox 4\%, } \\
\text { Protestant (including Lutheran, evangelical Christian Baptist) } \\
\mathbf{2 \%} \text {, none } 10 \%\end{array}$ \\
\hline 9 & Germany & $\begin{array}{l}\text { Christian Protestant } 34 \% \text {, Roman Catholic } 34 \% \text {, Islam } 4 \% \text {, } \\
\text { Unaffiliated or other } 28 \%\end{array}$ \\
\hline 10 & Netherland & $\begin{array}{l}\text { Christian Roman Catholic 31\%, Dutch Reformed 13\%, } \\
\text { Calvinist 7\%, Islam 6\%, none 41\% }\end{array}$ \\
\hline 11 & Belgium & Christian Roman Catholic $75 \%$, Protestant or other $25 \%$ \\
\hline 12 & Czech Rep. & $\begin{array}{l}\text { Christian Roman Catholic 27\%, Protestant 2\%, unaffiliated } \\
59 \%\end{array}$ \\
\hline 13 & Austria & $\begin{array}{l}\text { Christian Roman Catholic } 74 \% \text {, Protestant 5\%, Islam 4\%, } \\
\text { none } 12 \%\end{array}$ \\
\hline 14 & Switzerland & $\begin{array}{l}\text { Christian Zionist (a blend of Christianity and indigenous } \\
\text { ancestral worship) 40\%; Roman Catholic 20\%; Muslim 10\%; } \\
\text { Anglican, Bahai, Methodist, Mormon, Jewish, and other } 30 \%\end{array}$ \\
\hline
\end{tabular}


Serhii O. Komnatnyi, Oleg S. Sheremet, Viacheslav E. Suslykov, Kateryna S. Lisova y Stepan D. Svorak

784 The role of the factors determining national character in building civil society

\begin{tabular}{|l|l|l|}
\hline 15 & Ireland & $\begin{array}{l}\text { Christian Roman Catholic 88\%, Church of Ireland 3\%, other } \\
\text { Christian 2\%, none 4\% }\end{array}$ \\
\hline 16 & Portugal & Christian Roman Catholic 94\% \\
\hline 17 & $\begin{array}{l}\text { New } \\
\text { Zeeland }\end{array}$ & $\begin{array}{l}\text { Christian Anglican 15\%, Presbyterian 11\%, Methodist 3\%, } \\
\text { Pentecostal 2\%, Baptist 1\%, Roman Catholic 12\%, other } \\
\text { Christian 9\%, none 26\% }\end{array}$ \\
\hline 18 & Uruguay & Christian Roman Catholic 66\%, Protestant 2\%, Jewish 1\% \\
\hline 19 & Surinam & $\begin{array}{l}\text { Christian Protestant 25.2\% (predominantly Moravian), } \\
\text { Roman Catholic 22.8\%, Hindu 27.4\%, Islam 19.6\%, } \\
\text { indigenous 5\% }\end{array}$ \\
\hline
\end{tabular}

Source: Based on Pew Research Center (2020).

Table 4. Religious factor in "closed-society" countries

\begin{tabular}{|c|c|c|}
\hline \# & Country & Religious denominations \\
\hline 1 & China & $\begin{array}{l}\text { Officially atheist Daoist (Taoist) 22\%, Buddhist } 18 \% \text {, } \\
\text { Christian } 5 \% \text {, Muslim } 2 \% \text {, none } 52 \%\end{array}$ \\
\hline 2 & $\begin{array}{l}\text { Lao People } \\
\text { Democratic Rep. }\end{array}$ & $\begin{array}{l}\text { Buddhist 60\%, animist and other 40\% (including } \\
\text { Christian 2\%) }\end{array}$ \\
\hline 3 & Viet Nam & $\begin{array}{l}\text { Officially atheist Folk religion } 45 \% \text {, Buddhist } 16,5 \% \text {, } \\
\text { Catholic } 7 \% \text {, Protestant } 1 \% \text {, }\end{array}$ \\
\hline 4 & Uzbekistan & Muslim (mostly Sunnis) 88\%, Eastern Orthodox 9\% \\
\hline 5 & Turkmenistan & Muslim 89\%, Eastern Orthodox 9\%, unknown 2\% \\
\hline 6 & $\begin{array}{l}\text { Iran Islamic } \\
\text { Rep. }\end{array}$ & $\begin{array}{l}\text { Muslim 98\% (Shi'a 89\%, Sunni 9\%); Zoroastrian, } \\
\text { Jewish, Christian, and Baha'i 2\% }\end{array}$ \\
\hline 7 & Azerbaijan & $\begin{array}{l}\text { Muslim } 93 \% \text {, Russian Orthodox } 3 \% \text {, Armenian } \\
\text { Orthodox } 2 \% \text {, other } 2 \%\end{array}$ \\
\hline 8 & Iraq & $\begin{array}{l}\text { Muslim } 97 \% \text { (Shiite } 60 \% ? 65 \% \text {, Sunni } 32 \% ? 37 \% \text { ), } \\
\text { Christian or other } 3 \%\end{array}$ \\
\hline 9 & $\begin{array}{l}\text { Syrian Arab } \\
\text { Rep. }\end{array}$ & $\begin{array}{l}\text { Muslim (Sunni).74\%; Alawite, Druze, and other Islamic } \\
\text { sects 16\%; Christian (various sects) 10\%; Jewish (tiny } \\
\text { communities in Damascus, Al Qamishli, and Aleppo) }\end{array}$ \\
\hline 10 & Saudi Arabia & Muslim 100\% \\
\hline 11 & Yemen & $\begin{array}{l}\text { Muslim (including Sunni and Shiite), small numbers of } \\
\text { Jewish, Christian, and Hindu }\end{array}$ \\
\hline 12 & Eritrea & $\begin{array}{l}\text { Christian (Eritrean Orthodox Christianity, Roman } \\
\text { Catholic, Protestant) 50\%, Muslim 48\% }\end{array}$ \\
\hline 13 & Egypt & $\begin{array}{l}\text { Muslim (mostly Sunni) 90\%, Coptic 9\%, Christian 1\%, } \\
\text { other 6\% }\end{array}$ \\
\hline 14 & Libya & Muslim (Sunni) 97\% \\
\hline 15 & South Sudan & Christian 60,5\% Muslim 20\% \\
\hline
\end{tabular}




\begin{tabular}{|c|l|l|}
\hline 16 & $\begin{array}{l}\text { Central African } \\
\text { Rep. }\end{array}$ & $\begin{array}{l}\text { Christian 50\% (Protestant and Roman Catholic - } \\
\text { both with animist influence - 25\% each), Muslim 15\% } \\
\text { indigenous beliefs 35\%, }\end{array}$ \\
\hline 17 & $\begin{array}{l}\text { Equatorial } \\
\text { Guinea }\end{array}$ & Muslim 85\%, Christian 8\%, indigenous 7\% \\
\hline 18 & Cuba & $\begin{array}{l}\text { Christian predominantly Roman Catholic and Santera } \\
\text { (Afro-Cuban syncretic religion) }\end{array}$ \\
\hline
\end{tabular}

Source: Based on Pew Research Center (2020).

The Table 3 demonstrates that 100\% of "open-society" countries are Christian. Roman Catholics have the majority in 9 countries, Protestants have a clear majority in 7 countries, and 3 countries have some balance. The orthodox denomination has some impact in Estonia. Such Orthodox countries as Greece, Bulgaria, Romania, and Northern Macedonia are categorized by CIVICUS (2019) as "narrowed".

Out of the 18 "closed-society" countries, 11 countries (61\%) are predominantly Islamic, 3 countries (16.7\%) are predominantly Christian, and 1 (Eritrea) is divided almost equally. East religions (Daoism, Buddhism, and others) have a traditional impact in 3 countries (16.7\%).

The third block (Tables 5 and 6 ) reveals the influence of the happiness index on the state of civil society.

Table 5. Religious factor in "closed-society" countries

\begin{tabular}{|r|l|l|l|}
\hline$\#$ & Country & Place in WHR 2020 & Index \\
\hline 1 & Finland & 1 & 7.809 \\
\hline 2 & Denmark & 2 & 7.646 \\
\hline 3 & Switzerland & 3 & 7.560 \\
\hline 4 & Iceland & 4 & 7.504 \\
\hline 5 & Norway & 5 & 7.488 \\
\hline 6 & Netherland & 6 & 7.449 \\
\hline 7 & Sweden & 7 & 7.353 \\
\hline 8 & New Zeeland & 8 & 7.300 \\
\hline 9 & Austria & 9 & 7.294 \\
\hline 10 & Canada & 11 & 7.232 \\
\hline 11 & Ireland & 16 & 7.094 \\
\hline 12 & Germany & 17 & 7.076 \\
\hline
\end{tabular}


Serhii O. Komnatnyi, Oleg S. Sheremet, Viacheslav E. Suslykov, Kateryna S. Lisova y Stepan D. Svorak

\begin{tabular}{|l|l|l|l|}
\hline 13 & Czech Rep. & 19 & 6.911 \\
\hline 14 & Belgium & 20 & 6.864 \\
\hline 15 & Uruguay & 26 & 6.440 \\
\hline 16 & Lithuania & 41 & 6.215 \\
\hline 17 & Estonia & 51 & 6.022 \\
\hline 18 & Portugal & 59 & 5.911 \\
\hline 19 & Surinam & - & no data \\
\hline
\end{tabular}

Source: Based on Pew Research Center (2020).

Table 6. Happiness factor in "closed-society" countries

\begin{tabular}{|l|l|l|l|}
\hline$\#$ & Country & Place in WHR 2020 & Index \\
\hline 1 & Saudi Arabia & 27 & 6.406 \\
\hline 2 & Uzbekistan & 38 & 6.258 \\
\hline 3 & Viet Nam & 83 & 5.353 \\
\hline 4 & Azerbaijan & 89 & 5.165 \\
\hline 5 & China & 94 & 5.124 \\
\hline 6 & Turkmenistan & 96 & 5.119 \\
\hline 7 & Equatorial Guinea & 102 & 4.949 \\
\hline 8 & Lao People Democratic Rep. & 104 & 4.889 \\
\hline 9 & Iraq & 110 & 4.785 \\
\hline 10 & Iran Islamic Rep. & 118 & 4.672 \\
\hline 11 & Egypt & 138 & 4.151 \\
\hline 12 & Yemen & 146 & 3.527 \\
\hline 13 & Central African Rep. & 149 & 3.476 \\
\hline 14 & Syrian Arab Rep. & 150 & 3.462 \\
\hline 15 & South Sudan & 152 & 2.817 \\
\hline 16 & Eritrea & - & no data \\
\hline 17 & Libya & - & no data \\
\hline 18 & Cuba & - & no data \\
\hline & & & \\
\hline
\end{tabular}

Source: Based on Pew Research Center (2020). 
All "open society" countries, in which the World Happiness Report Research-2020 (Helliwell et al., 2020) was conducted, occupy positions in the top half of the ranking, which includes 153 countries. There are 14 countries (77.8\%) in the top twenty. However, 3 countries from the list of "open society" are inferior to the top countries from the list of "closed society". In "open society" countries the average happiness index is 7.065.

Only 2 of the 15 "closed-society" countries, in which the WHR research was conducted, occupy positions in the top half of the ranking. There are 13 countries $(86.6 \%)$ in the bottom half of the rating, of which $5(33.3 \%)$ are among the unhappiest $10 \%$ of the world. The average happiness index in "closed-society" countries is 4.677 .

\section{Discussion}

The presented results take the interpretation of civil society beyond the narrow frameworks of institutionalism. After all, these frameworks limit the subject of research by the actual existence of institutions and organizations of civil society in all spheres of life. They involve the use of a predominantly statistical method. This method shows the state but does not reveal the driving forces of the process of building civil society as in some political systems either on regional or on the global level (Feenstra, 2017). Institutionalism does not answer the fundamental questions: Why in some countries stable and influential entities of civil society were formed independently, while in other countries public organizations, even created by external forces, are disintegrated, or work inefficiently? Why in some countries the low assessment of the state of civil society development due to the absence or a small number of formal institutions and organizations of civil society was inadequate, given the real impact of civil society on sociopolitical processes? The forecasts that were made based on institutionalism fell through and problems seem insurmountable.

The limitation of the institutional approach is especially evident when assessing the influence of religion on building civil society. This approach leads to superficial conclusions. Omelicheva and Ahmed (2018) emphasize: "Religiosity, by itself, often serves as a deterrent rather than mobilizing force for political engagement, regardless the denominational differences. It is the membership in religious organizations and other voluntary associations of a secular nature that make individuals more likely to engage in political activity". It is obvious that these researchers habitually regard religion as a set of social institutions in isolation from its moral influence on the formation of a national ethos. And there has been too little investigation of how individual religious beliefs and practices affect interactions and outcomes within organizations, including educational, legal, political, and occupational (Glass, 2019). 
Vamstad (2020) argues that structural barriers to the formation of a community, Muslims in the present case, are neither fixed nor immutable. Mclean and Mcmillan (2009) argue that civil society can actively foster antidemocratic agendas that propel young democracies on an autocratic path. But they did not reveal the root causes of these strong autocratic features.

Similarly, institutionalists consider the inherently moral problems of civil society in isolation from understanding the specifics of national character. In particular, researchers are exploring such issues as the effect of generalized trust on political participation, the translating individual-level explanations of differences in political participation to an organizational level, and citizens' initiatives (Inkeles, 2017; Kenny, 2020) only at the organizational level. They do not correlate these issues with natural, social and psychological factors.

On the contrary, our research proves that these factors with a high degree of correlation are reflected in the essential characteristics of civil society, which CIVICUS summarizes in the categories of "open", "narrowed", "repressed" and "closed". The influence of climatic and religious factors on building civil society is due to the particularly stable archetypes of human relations, which they predetermine. Thus, the research confirms the identification of national character not only with the innate characteristics of a group, but involves the identification of people, ethnicity, and races according to specific indomitable cultural characteristics (Wiarda, 2016).

Our research shows that it is not the institutions themselves that are important, but the "spirit of the people", which is expressed in the national character and mentality. Such factors as: (a) climatic conditions; (b) the religious precepts that determine its ethos are often subconscious; (c) the national "happiness formula", which determines a certain goal in the process of social interaction, reflect the different levels of national character.

But issues concerning large countries that are located in several climatic zones, as well as countries that do not have a dominant religion or denomination, remain controversial. These issues need to be considered in separate studies. For example, Sun (2016) goes this way exploring the Chinese national character. However, these studies cannot replace a global generalized view on the problem, where certain exceptions only confirm the general rule.

Issues of the so-called "split countries", such as Korea, also remain controversial and show cultural-historic contentious system. Such examples show that the national character formed under the influence of climate and religion has different manifestations and building of civil society also depends on the course of historical events. So, the issue must be addressed as to whether political institutions shape national character more or less than they are shaped by it (Charlesworth, 1967). 
The criterion of the national "happiness formula" proposed in this study helps to solve this long-standing dilemma. If the linearity of the influence of climatic and religious actors is obvious, the influence of the happiness factor found in the study through the use of World Happiness Report 2020 (Helliwell et al., 2020) data is not so unambiguous. The definition of Helliwell et al., (2020), - "several kinds of individual and social trust and social connections" - should be seen as components of national "happiness formula", which determines the national character. After all, the question of whether the national "happiness formula" affects building civil society in the country, or, conversely, the state of civil society affects the feeling of happiness is really debatable. Values that collectively determine the perception of happiness within a particular social group are the basis of ethos. Thus, the image of happiness that dominates a certain nation both on a conscious and unconscious level determines its mentality. On the one hand, happiness is an essential goal of civil society, and, on the other hand, the specifics of the happy feeling, the so-called "happiness formula", as a determinant of national character, affects the formation of civil society space.

Thus, based on WHR data, which we compared with the state of civil society in different countries around the world, we concluded that building civil society is two-stage. Initially, the inherent features of the national character (ethos, national "happiness formula") form a civil society through social communication. Then, the specifics of the established institutions of civil society affect the individual and group mentality through public opinion, trust, and sanctions.

So, the results of our study develop the provisions of the system functional approach, which gained popularity in the second decade of the 21st century. The authors of this approach focus on the analysis of the processes of functioning, connections, and interaction of various elements, institutions and organizations of civil society. For example, Kenny (2020) interprets civil society as a dense network of groups, communities, networks, and ties that stand between the individual and the modern state.

In general, this approach can be agreed upon. But the results show that to understand the patterns of building civil society, it is necessary to go beyond the study of its forms, norms and spaces, which is presented in the fundamental collective work The Oxford Handbook of Civil Society edited by Edwards (2013). In contrast to the materials presented in this book, the results of our research show that the emphasis on anthropological aspects of the geometry of human relations makes the system-functional approach more effective. On the one hand, it becomes deeper, because it is immersed in the depths of the human subconscious, where archetypes of national character are hidden. And, on the other hand, it becomes broader, because it brings a research from the case-study of one country to the global level. 
The results of the research of the impact of national peculiarities on building civil society as a whole are in line with modern studies. According to the latter, civil society is still invoked by many of its advocates as a synonym for the values of authenticity and belonging, neither of which, as assumed, can be achieved in politics or economic life (Kenny, 2020). But these results reject institutionalism, which is entrenched in the interpretation of the national character as well.

\section{Conclusion}

The research expands and deepens the system functional approach to the evaluation of building civil society. It overcomes the flaws of instrumentalism and presents a view of civil society through the prism of an anthropologist.

The author compared the following factors that affect the type of national character: (a) the climatic conditions; (b) the dominant religion; c) understanding of happiness.

The comparison shows that:

- the correlation of a location in a temperate climate zone with the inclusion of a country in an "open-society" group is $84 \%$, and a location in a hot climate zone with the inclusion of a country in a "closed-society" group is $94.4 \%$.

- the correlation of Christianity as dominant religion with the inclusion of a country in an "open-society" group is 100\%, and of Islam as predominant religion with the inclusion of a country in a "closed-society" group is $61 \%$.

- $77.8 \%$ "open-society" countries are in the top twenty of the World Happiness Report rating, in "open-society" countries the average index of happiness is 7.065, and 86.6\% "closed-society" countries are in the bottom half of the rating, of which $33.3 \%$ are among the unhappiest $10 \%$ of the world; the average index of happiness in "closed-society" countries is 4.677 .

Thus, the research reliably proves that the factors which determine the specifics of national character and political mentality are reflected with a high degree of correlation in the essential characteristics of civil society through certain stable recurring stereotypes of human relations.

The hot climate, which affects 'hot' temperament as a physiological background of southern character, combined with harsh sanctions that ensure the observance of moral norms in Islam, shapes the geometry of human relations according to the patriarchal-paternalistic formula 
"domination - submission". These factors form the type of national character that determines the specifics of closed societies.

On the contrary, there are three interrelated components of Nordic national character, which forms an open civil society: (a) the temperament inherent in the inhabitants of temperate countries, (b) combined with the Christian ethos of love and charity, (c) which forms a specific cooperative "happiness formula", as "several kinds of individual and social trust and social connections".

Civil society is built in two stages. Initially, the peculiarities of the national character (temperament, ethos, national "happiness formula") form a civil society through social communication. The specifics of the established institutions of civil society affect the individual and group mentality through public opinion, trust, reputation, and sanctions.

The research results are important for the evaluation of building civil society and its development prospects in different countries and regions of the world.

Further research in this area is related to the study of other aspects of the impact of national character and political mentality on civil society, in particular in the field of social media.

The calculations carried out by the author make it possible to solve the assigned tasks and achieve the set research goal.

The comparison of different countries civil society's state with the climatic conditions of their location shows that the correlation of a location in a temperate climate zone with the inclusion of a country in an "opensociety" group is $84 \%$, and a location in a hot climate zone with the inclusion of a country in a "closed-society" group is $94.4 \%$;

The collation of such key characteristics of civil society as 'openness' and 'closedness' with the dominant religion demonstrates that the correlation of Christianity as dominant religion with the inclusion of a country in an "open-society" group is $100 \%$, and of Islam as predominant religion with the inclusion of a country in a "closed-society" group is $61 \%$.

The analysis of the dependence of civil society's state on the factors that determine the feeling of happiness inherent in a certain type of national character reveals that $77.8 \%$ "open-society" countries are in the top twenty of the World Happiness Report rating, in "open-society" countries the average index of happiness is 7.065, and 86.6\% "closed-society" countries are in the bottom half of the rating, of which $33.3 \%$ are among the unhappiest $10 \%$ of the world; the average index of happiness in "closed-society" countries is 4.677 . 
Serhii O. Komnatnyi, Oleg S. Sheremet, Viacheslav E. Suslykov, Kateryna S. Lisova y Stepan D. Svorak

Thus, our research of the role of external factors and internal determinants of national character and political mentality in building and functioning of civil society reliably proves that such factors and determinants as: (a) the climatic conditions; (b) the dominant religion; c) understanding of happiness are reflected with a high degree of correlation in the essential characteristics of civil society through certain stable recurring stereotypes of human relations.

The hot climate, which affects 'hot' temperament as a physiological background of a southern character, combined with harsh sanctions that ensure the observance of moral norms in Islam, shapes the geometry of human relations according to the patriarchal-paternalistic formula "domination - submission". These factors form the type of national character that determines the specifics of closed societies.

On the contrary, there are three interrelated components of Nordic national character, which forms an open civil society: (a) the temperament inherent in the inhabitants of temperate countries, (b) combined with the Christian ethos of love and charity, (c) which forms a specific cooperative "happiness formula", as "several kinds of individual and social trust and social connections".

The research results are important for the evaluation of building civil society and its development prospects in different countries and regions of the world.

Further research in this area is related to the study of other aspects of the impact of national character and political mentality on civil society, particularly in social media.

\section{Bibliographic References}

BIDEN, Joseph R. 2020. Why America must lead again. Rescuing U. S. foreign policy after Trump. Available online. In: https://www.foreignaffairs. com/articles/united-states/2020-01-23/why-america-must-lead-again. Consultation date: 04/23/2021.

BILALI, Rezarta; IQBAL, Yeshim; ÇELIK, Ayşe Betül. 2018. “The role of national identity, religious identity, and intergroup contact on social distance across multiple social divides in Turkey" In International Journal of Intercultural Relations. Vol. 5, pp. 73-85. Available online. In: https:// doi.org/10.1016/j.ijintrel.2018.04.007. Consultation date: 04/23/2021.

CAMBRIDGE DICTIONARY. 2021. Ethos. Available online. In: https:// dictionary.cambridge.org/dictionary/english/ethos. Consultation date: 04/23/2021. 
CHARLESWORTH, James. 1967. "National character in the perspective of political science" In the Annals of the American Academy of Political and Social Science, vol. 370, No. 1, pp. 23-29.

CIA WORLD FACTBOOK. 2020. World Religions. Available online. In: https://www.infoplease.com/world/social-statistics/world-religions. Consultation date: 04/23/2021.

CIVICUS. 2019. State of Civil Society Report. Available online. In: https://www. civicus.org/index.php/state-of-civil-society-report-2019. Consultation date: $04 / 23 / 2021$.

COLLINS ONLINE ENGLISH DICTIONARY. 2021. Civil Society. Available online. In: https://www.collinsdictionary.com/dictionary/english/civilsociety. Consultation date: 04/23/2021.

DINGLEY, James. 2009. "Religion, truth, national identity and social meaning: The example of Northern Ireland" In National Identities. Vol. 11, No. 4, pp. 367-383. Available online. In: https://doi. org/10.1080/14608940903321994. Consultation date: 04/23/2021.

EDWARDS, Michael. 2013. Introduction: Civil Society and the Geometry of Human Relations. In M. Edwards (ed.), “The Oxford Handbook of Civil Society”. Oxford University Press, Oxford, UK, pp. 1-12. Available online. In: $\quad$ https://doi.org/10.1093/oxfordhb/9780195398571.013.0001. Consultation date: 04/23/2021.

FEENSTRA, Ramon. 2017. "Essay: Rethinking Global Civil Society and the Public Sphere in the Age of Pro-democracy Movements" In Journal of Civil Society. Vol. 13, No. 3, pp. 337-348. Available online. In: https://doi. org/10.1080/17448689.2017.1359886. Consultation date: 04/23/2020.

GLASS, Jennifer. 2019. “Why Aren't We Paying Attention? Religion and Politics in Everyday Life" In Sociology of Religion. Vol. 8o, pp. 9-27. Available online. In: https://doi.org/10.1093/socrel/sry041. Consultation date: 04/23/2020.

HELLIWELL, John; LAYARD, Richard; SACHS, Jeffrey; DE NEVE, Jan Emmanuel. (eds.). (2020). World Happiness Report 2020. Sustainable Development. Available online. In: https://worldhappiness.report/ ed/2020/\#read. Consultation date: 04/23/2021.

INKELES, Alex. 2017. National Character and Modern Political Systems: A Psycho-Social Perspective. In A. Inkeles (ed.), National Character. Routledge, New York, NY, pp. 211-250. Available online. In: https://doi. org/10.4324/9781315125053-6. Consultation date: 04/23/2020. 
Serhii O. Komnatnyi, Oleg S. Sheremet, Viacheslav E. Suslykov, Kateryna S. Lisova y Stepan D. Svorak

KENNY, Michael. 2020. Civil society. Available online. In: https://www. britannica.com/topic/civil-society/Contemporary-political-discourse. Consultation date: 04/23/2021.

LORD, Carnes. 2013. Aristotle's Politics. (2nd ed.). University of Chicago Press, Chicago, IL. London, UK.

MAHAJAN, Gurpreet. 2021. "Does a plural civil society matter? Reflecting on the varieties of associational life in India" In Journal of Civil Society. Vol. 17, No. 1, pp. 5-17. Available online. In: https://doi.org/10.1080/174486 89.2021.1886761. Consultation date: 04/23/2020.

MCCRAE, Robert; TERRACCIANO, Antonio; REALO, Anu; ALLIK, Jüri. 2007. "Climatic Warmth and National Wealth: Some Culture-Level Determinants of National Character Stereotypes" In: European Journal of Personality. Vol. 21, No. 8, pp. 953-976. Available online. In: https:// doi.org/10.1002/per.647. Consultation date: 04/23/2020.

MCLEAN, Iain; MCMILLAN, Alistair. 2009. Civil Society. In The Concise Oxford Dictionary of Politics. (3rd ed.). Oxford University Press, Oxford, UK. Available online. In: https://doi.org/10.1093/ acref/9780199207800.001.0001. Consultation date: 04/23/2020.

OMELICHEVA, Mariya; AHMED, Ranya. 2018. "Religion and politics: examining the impact of faith on political participation" In Religion, State and Society. Vol. 46, No. 1, pp. 4-25. Available online. In: https://doi.org /10.1080/09637494.2017.1363345. Consultation date: 04/23/2020.

PEW RESEARCH CENTER. 2020. The Global Religious Landscape: A Report on the Size and Distribution of the World's Major Religious Groups. Available online. In: https://assets.pewresearch.org/wp-content/ uploads/sites/11/2020/01/global-religion-full.pdf. Consultation date: 04/21/2021.

STEWART, Philip. 2018. Montesquieu's The Spirit of the Law. Available online. In: http://montesquieu.ens-lyon.fr/spip.php?rubrique186. Consultation date: $04 / 23 / 2021$.

SUN, Warren. 2016. The Chinese National Character: From Nationhood to Individuality. Routledge, New York, NY.

WEBER, Max. (2002). The Protestant Ethic and The Spirit of Capitalism. Transl. by P. Baehr \& Gordon C. W. Penguin Books, London, UK.

WIARDA, Howard. 2016. Political Culture, Political Science, and Identity Politics: An Uneasy Alliance. Routledge, New York, NY. 
WORLD METEOROLOGICAL ORGANIZATION. 2020a. Climate Zone Shiny Map. Available online. In: https://community.rstudio.com/t/climatezone-shiny-map/56366. Consultation date: 04/24/2021.

WORLD METEOROLOGICAL ORGANIZATION. 202ob. Provisional Report on the State of the Global Climate 2020. Available online. In: https://library.wmo.int/index.php?lvl=notice_display\&id=21804\#. YGOajtIzbIU. Consultation date: 04/24/2021.

WORLD METEOROLOGICAL ORGANIZATION. 2021. World Climate Maps. Available online. In: https://www.climate-charts.com/World-ClimateMaps.html. Consultation date: 04/24/2021.

VAMSTAD, Johan. 2020. "Giving to be civil or civic? - A social origins analysis of charitable giving in Sweden" In Journal of Civil Society. Vol. 16, No. 1, pp. 1-14. Available online. In: https://doi.org/10.1080/17448689.2020. 1717158. Consultation date: 04/23/2021. 

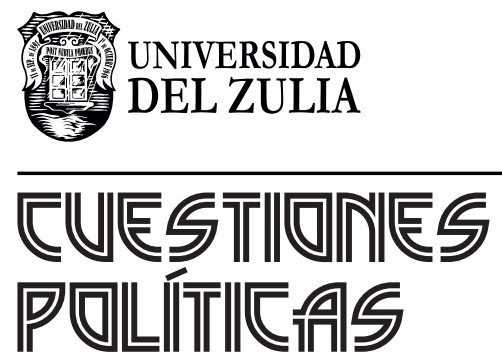

Vol.39 No 69

Esta revista fue editada en formato digital y publicada en julio de 2021, por el Fondo Editorial Serbiluz, Universidad del Zulia. Maracaibo-Venezuela 